\title{
Therapeutic Epinephrine
}

National Cancer Institute

\section{Source}

National Cancer Institute. Therapeutic Epinephrine. NCI Thesaurus. Code C473.

The synthetic form of the naturally occurring sympathomimetic amine with vasoconstricting, intraocular pressure-reducing, and bronchodilating activities. By stimulating vascular alpha-adrenergic receptors, epinephrine causes vasoconstriction, thereby increasing vascular resistance and blood pressure. When administered in the conjunctiva, this agent binds to alpha-adrenergic receptors in the iris sphincter muscle, resulting in vasoconstriction, a decrease in the production of aqueous humor, and a lowering of intraocular pressure. Through its beta1 receptor-stimulating actions, epinephrine increases the force and rate of myocardial contraction and relaxes bronchial smooth muscle, resulting in bronchodilation. 